\title{
Prospecting Ocupation Influencer Service using Prototyping Method
}

\author{
Beny Machmud Putra \\ Research Student \\ Department of Computer Science, \\ Faculty of Information System, Mercu Buana University \\ Jakarta, Indonesia \\ Helfina Razi Putri \\ Research Student \\ Department of Computer Science, \\ Faculty of Information System, Mercu Buana University \\ Jakarta, Indonesia
}

\author{
Muhammad Iqbal Dyratama \\ Research Student \\ Department of Computer Science, \\ Faculty of Information System, Mercu Buana University \\ Jakarta, Indonesia
}

\author{
Inge Handriani \\ Lecture \\ Department of Computer Science, \\ Faculty of Information System, Mercu Buana University \\ Jakarta, Indonesia
}

\begin{abstract}
As for now, the public knows the product not only through advertisements on television, print media, and billboards, but can be through social media. So, many companies in Indonesia are competing to introduce their products through social media. However, today many companies are having trouble finding influencers, and vice versa where influencers are also having trouble getting clients. This study aims to improve the effectiveness and efficiency of the search process for advertising services for influencers and clients. The system business processes that occur in the field, in this study the system analysis is done using the Fishbone method. This research uses a prototyping method approach. This service search system creates a bridge of communication and transactions between influencers and clients. This system is the first system in Indonesia that is equipped with digital payment facilities and self-verification as internal control.
\end{abstract}

Keywords-Social media marketing; digital marketing; influencer; social media

\section{INTRODUCTION}

The rapid development of technology causing information to spread wide and fast. This fact has a positive impact on several fields of work in Indonesia, one of which is Digital Marketing. Digital Marketing is a form of marketing through digital channels, several digital channels that are often found in the field of Digital Marketing, among others; social media, websites, e-mail, search systems and applications (Patel, 2016), this is also supported by Neil Patel's statement in his article entitled Digital Marketing Made Simple: A Step-by-Step Guide. Digital Marketing work can be maximized by utilizing social media, because social media has the characteristics of being able to disseminate information precisely and clearly.

As an illustration, marketing is no longer just selling goods or services, but building a brand or product is also one of the activities in the marketing world. In this case, communication marketing is needed to support the level of success of Digital Marketing. Marketing communication is a series of processes to build communication with customers, the better the marketing communication, the higher the level of customer trust in a brand or product (Keller, 2007), according to Keller in his book entitled Marketing Management. In addition, marketing communication is a form of way to convey messages to the public regarding a brand or product (Siswanto, 2018). The rise of digital marketing in Indonesia is supported by very high internet growth, this statement is supported by survey data of internet users through APJI (Association of Indonesian Internet Service Users) in 2017 reaching 143.26 Million Users, which means an increase from 2016 which was 132.7 Million users of the total 262 million population of Indonesia (APJII, 2017). 


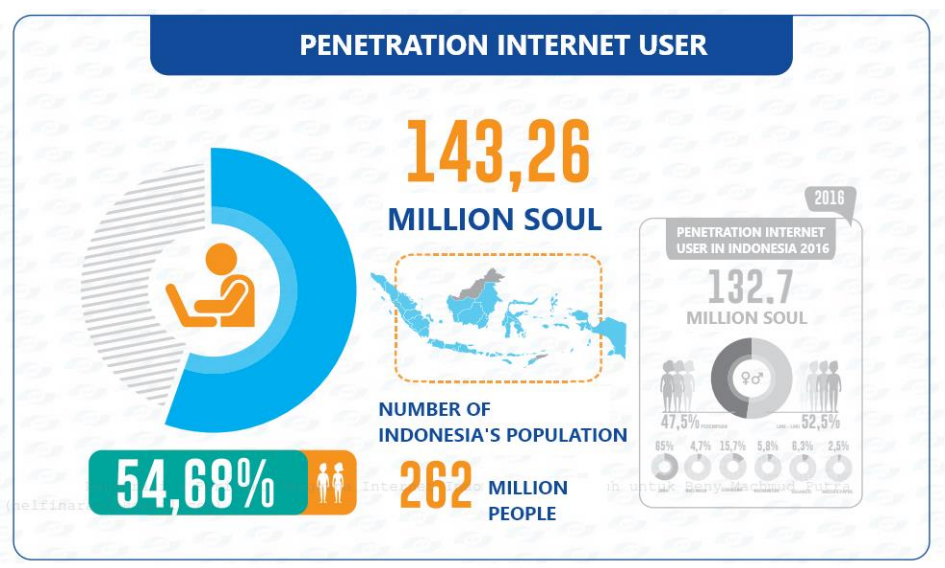

Figure 1 internet penetration in Indonesia

The number of internet users is directly proportional to the users of social media, where social media is one part of Digital Marketing. Digital marketing can help company building deeper relationship with customer (Royle \&
Laing, 2014). The following are data from APJI related services that are often accessed by Indonesian people:

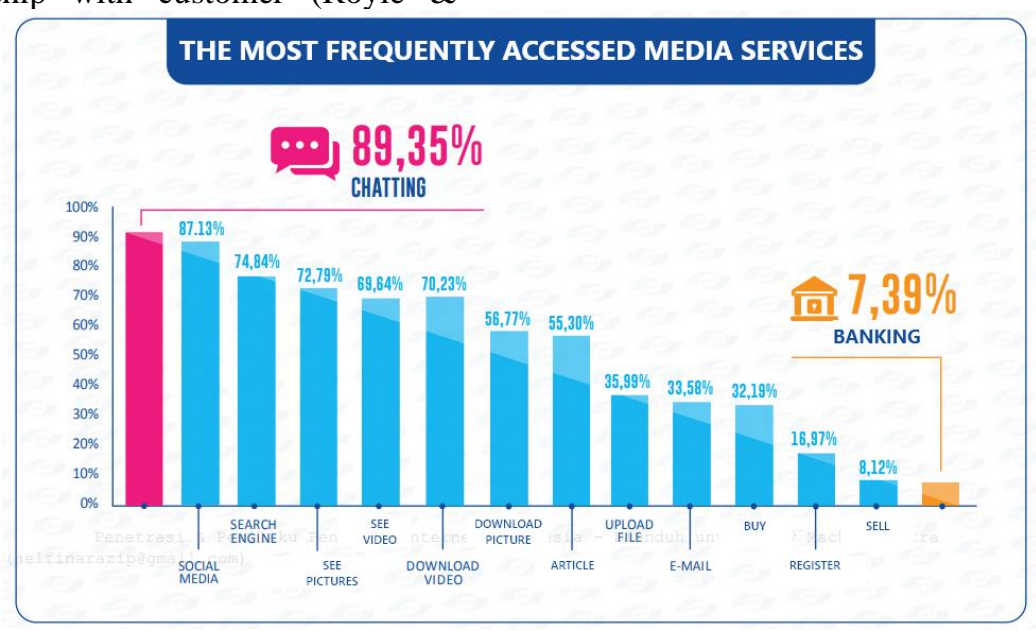

Figure 2 the most frequently accessed media services

In addition to chatting, social media is a platform that is often accessed by Indonesians and be one of the most marketing channel that can connect between companies and customer(SI, 2015). Social media is divided into several types; Facebook, Instagram, You Tube, Blog and Linked In(Whiting \& Williams, 2013). Other than that, social media has changed the communication process of a company's business to customers(Rapp, Beitelspacher, Grewal, \& Hughes, 2013). It is undeniable that the existence of social media is a lifestyle because all the information needed by the public comes from social media. Now days, people always create content in their social media (Romero, Galuba, Asur, \& Huberman, 2011). Microblogging Twitter and social network Facebook can increase potential user to engage with the brand(Stieglitz \& Dang-Xuan, 2013). The penetration of the internet and social media which continues to climb up makes the internet and social media become one of the best product marketing media. Other than that, social media can use as consumer habit tool tracker (Yadav, Joshi, \& Rahman,
2015). So, companies are competing to market their products through the internet and social media. Besides that social media can also be one way to easily build communication between companies and users and reach users they could not reach before (Pradiptarini, 2011). In the virtual world, currently social media is not just a place to communicate but also as one of the marketing strategies (Öztamur \& Karakadılar, 2014). Marketing through the internet and social media is expected to bring profitable business value to the company (Bashar, Ahmad, \& Wasiq, 2012). The use of social media in digital marketing activities must also have an appropriate communication strategy, because playing Digital Marketing in the realm of social media gives everyone the opportunity to share their opinions when they receive poor service and buy substandard products. So, a quality brand or product must be ensured before it is marketed, both in terms of the product or information delivery strategy. In this case, they need the help of influencers to market their products through social media, so that people are more familiar with these products, because no matter how big company budget 
is, digital campaign could be succeed if campaign gains attention of communities well (Dehghani, Niaki, Ramezani, \& Sali, 2016). Influencers can now be considered as opinion leaders in the digital age and become word of mouth strategies. Influencer is part of social media marketing that so that message can deliver is well (Vance $\&$ Howe, 2009). The Word of mouth strategy has become one of the marketing strategies that has been continuously applied in recent years. According to Xi Y. Leung in his journal entitled The Marketing Effectiveness Of Social Media In The Hotel Industry: A Comparison Of Facebook And Twitter word of mouth marketing strategy is the best strategy because people are free to express their opinions (Leung, Bai, \& Stahura, 2015). Someone who always follows all influencer's posts is called followers or subscribers (customers). Anyone who becomes The followers or The subscriber can be freely give their opinions and imitate them (Hafiar, 2017), from this statement it can be concluded that social media brings a drastic change to life someone, including the way they communicate and think (Sulistyo, 2018). Influencer is someone on social media who is known by many people and has a large number of followers, besides that an influencer is also able to influence the behavior and thoughts of his followers (Hariyanti \& Wirapraja, 2018). While bloggers are a group of people or someone who is a hobby or profession in writing through blog channels or websites. Blogger is an important factor in Digital Marketing activities because bloggers are able to lead opinions when someone searches for information related to brands or products through search sites such as; Google, Yahoo and others. Blogs become one of the media that can bring prospective buyers (Hanna, Rohm, \& Crittenden, 2011). A celebrity itself is someone who has popularity on social media, generally this celebrity is only famous for it uploads on social media, and not all celebrities are able to influence people's behavior and thinking. Influencer Marketing is seen as one of the best strategies for bringing in potential customers when marketing using social media (Hariyanti \& Wirapraja, 2018). In addition Influencer Marketing can also build a product or brand image through their social media accounts (Hermanda, Sumarwan, \& Tinaprilla, 2019). In building a brand or brand, influencers must know the demographics and nature of their followers, because according to We Are Social, entitled Trend Shopping Social in 2019, knowing the demographics of followers can influence the success of the campaign. However, this is not easy to do, because as product owners, they must choose influencers who have good quality and do not have a bad history in their career as influencers. Therefore, product owners or Digital Marketing practitioners need an influencer services search platform to help them find the right influencers for marketing activities. The search for influencers can be made easier by using a platform that has a marketplace concept, where clients can find influencers easily. Marketplace is an internet-based online media that functions as a place to conduct business activities and transactions between buyers and sellers (Putra, Nyoto, \& Pratiwi, 2017). In another explanation, the marketplace is a trading market where the seller or service provider offers a variety of goods or services via the internet, between service providers and buyers or service users who have never met or made physical contact. To increase user comfort, the influencer services search system is equipped with a payment system with electronic money. The emergence of non-cash payment instruments such as e-money in the payment system by Bank Indonesia is expected to be able to improve the country's economy (Pranoto \& Salsabila, 2018). This research is the first search for influencer services in Indonesia that uses electronic money payment systems and has 3 internal controls, among others; selfverification or know your customer, gradual payment or down payment, and each transaction is protected terms and conditions apply.

\section{STUDY OF LITERATURE}

\section{A. Influencer on Social Media Marketing}

Influencer is a person or community that can help promote a brand or product to the wider community. In fact, anyone can become an influencer marketing as long as the person has a community and is able to influence people's thinking power on a matter. In the world of Digital Marketing, Influencer Marketing is seen as one of the best strategies to bring prospective customers when doing marketing using social media (Hariyanti \& Wirapraja, 2018).

\section{B. Marketplace Influencer}

In general, a marketplace is a website or online application that supports transaction processes (services and goods) from various shops or parties. The transaction process through the market place namely; the buyer or service buyer selects the list of goods or services desired, then the system in the application or website market place will continue to the seller or service provider, after the order is accepted, the buyer is required to pay first the goods or services ordered then the seller or provider the service will send or do the service ordered. The concept of this marketplace is similar to the transaction processes in the market, the difference is that this process is more practical and efficient.

\section{Fishbone Diagram}

Fishbone diagram or fishbone is a method for improving analyzing system problems. In addition, this diagram is called a Cause and Effect diagram. The function of the Fishbone diagram is to identify and organize the causes that might arise from a specific effect and then separate the root causes, model accompanied by the Fishbone Diagram To Empower Analyzing Ability (Amita, 2015). The basically a fishbone diagram can be using to follow the needs below:

- Helps identify the root cause of a problem

- Help generate ideas for solutions to problems

- Assist in further investigation or fact finding

- Identifying actions to create the desired results

- Discuss the issue completely and neatly 


\section{RESEARCH METHOD}

Sources of research used in this study took the method of Library Research, (library research), then the data obtained were processed using data analysis using quantitative methods. The results of this study are presented using descriptive methods.

\section{Data collection technique}

The data collection methods used in completing this research include:

- Conducting interviews with 5 clients, from different companies. Then interviewed 3 people as influencers from various categories.

- Give questionnaires to 5 people on the client side, and 25 influencers.

- Documents obtained from sources from the Influencer include; Standard Operational Procedure (SOP), rate card (information related to honorarium for influencer services), evidence of work results such as insight data on the posting. In addition, the documents obtained from the client are invoices, payment agreement statements, quotations (offers from influencers), proof of payment from the client.

\section{Research Flow}

In conducting this research, systematic steps are taken so that what is desired can be achieved. Following are the proposed research steps:

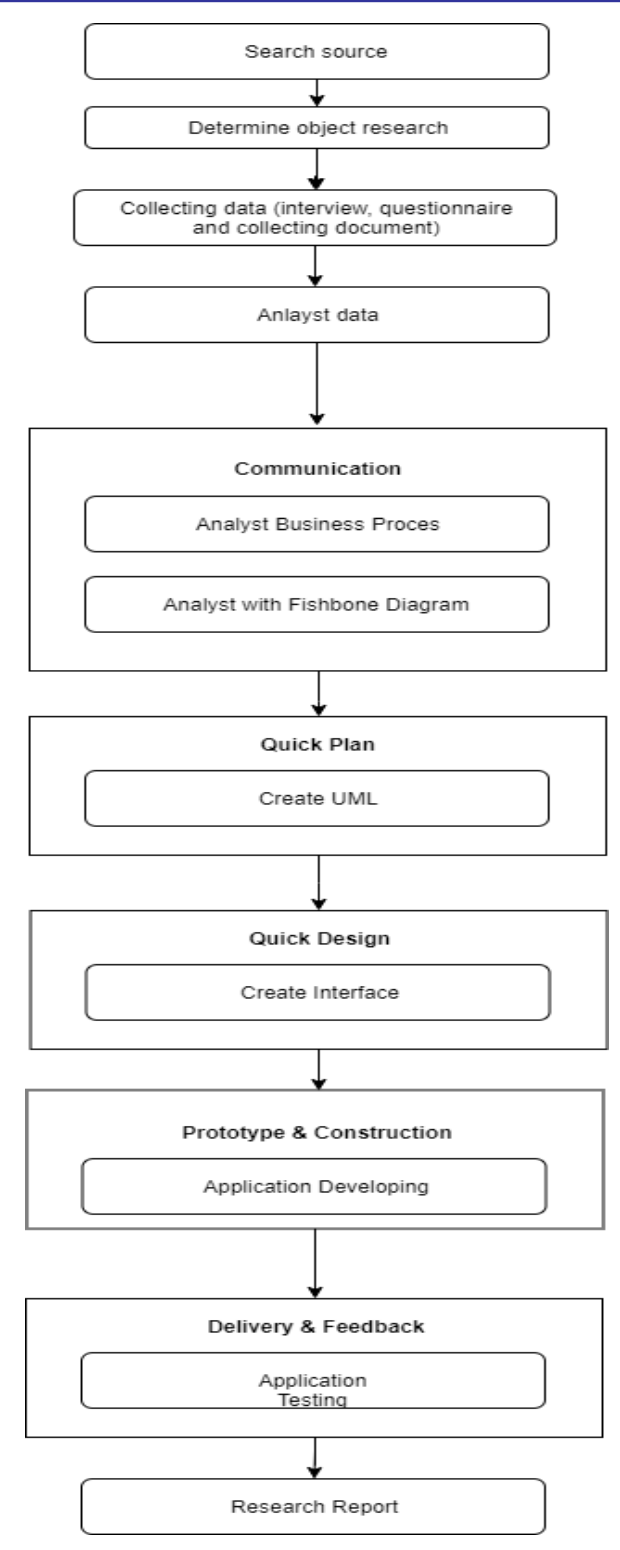

Figure 3 Research Flow

\section{RESULT AND DISCUSSION}

\section{A. Communication}

In this study has taken data from sources, so far the system that runs in the search for influencers involving clients and influencers from various companies such as the following: 


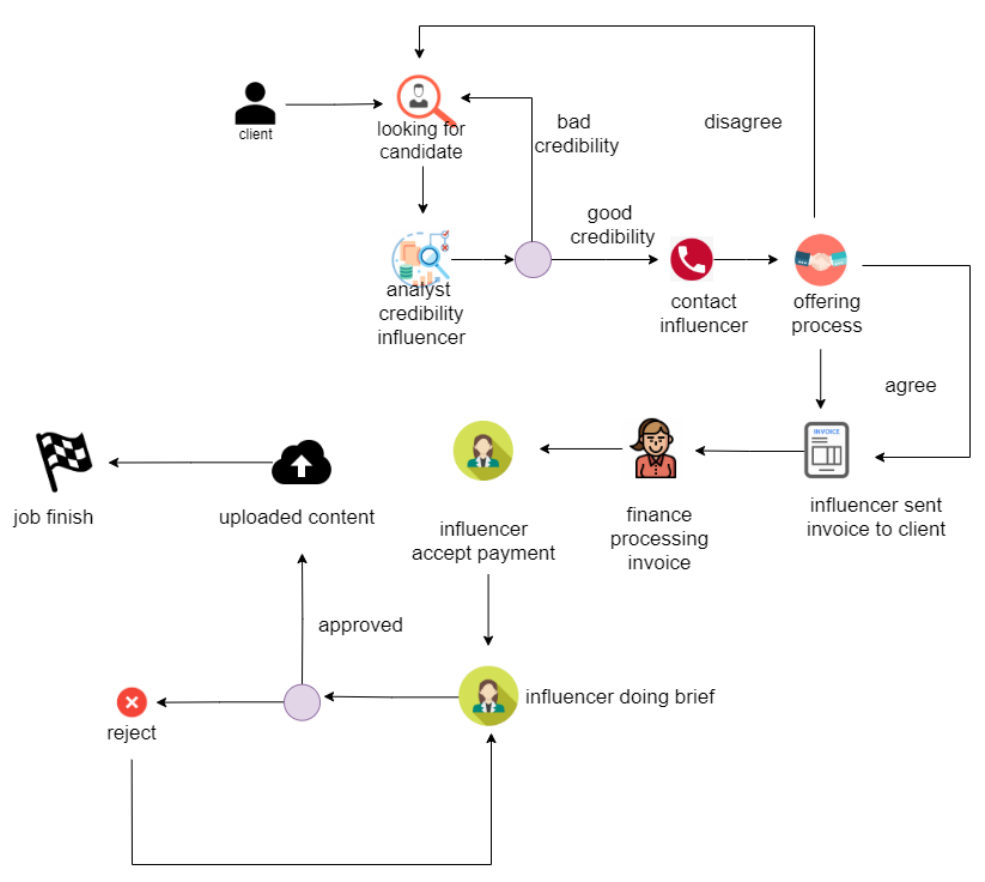

Figure 4 Business Process

This system procedure starts where;

1) Clients are looking for influencer candidates who match the campaign criteria through social media and search engines (google).

2) After finding an influencer candidate, the client analyzes whether the influencer has a good track record or not. If good, then continue, if not then return to the influencer search process.

3) After that, the third step is contacting the influencer to find out information related to the ratecard.

4) Next is, the client makes an offer and gives a little brief so that influencers have an overview of their work. If they disagree, the client returns to the influencers search process, if they agree the influencers go to the next process.

5) After agreeing, the influencer sends an invoice addressed to the client's finance.
6) After receiving an invoice, the client's finance processes the invoice payment.

7) Then after the payment is successfully made, the proof of payment is sent to the relevant influencer. Where this process marks the work the influencer can get started.

8) Influencers start working according to the client's brief.

9) After completing work, the influencer is required to approve the client. If the client agrees then the influencer uploads the content and the work is considered complete. If the client has a revision, the influencer must work on the revision until the client agrees

In the description of business processes that have been described, then analyzed using Cause and Effect Diagrams or Fishbone

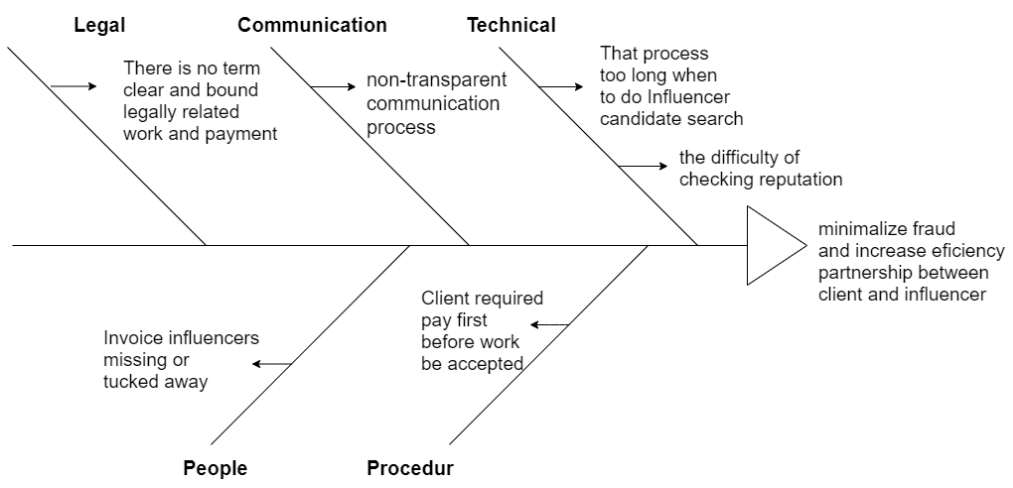

Figure 5 Fishbone Diagram 
From the explanation of business processes and analysis of these problems, there can be several system requirements that must be implemented, including;

1) Created search engine influencers search according to the desired category and filter in one platform

2) Made a review display of the work of influencers

3) A notification of cooperation offerings from clients is made for influencers in which the researcher hopes that the client will get a quick response

4) Created a form so that all communications and directions look more transparent
5) Popup agreement terms and conditions that contain the law are made and protect all transactions in the Veeralkan application

6) A phased payment method is created to minimize frauds that occur

7) Automatic invoices are made to speed up the payment process.

8) A transaction history is created

9) Made a payment method digitally with the name $\mathrm{V}$-pay.

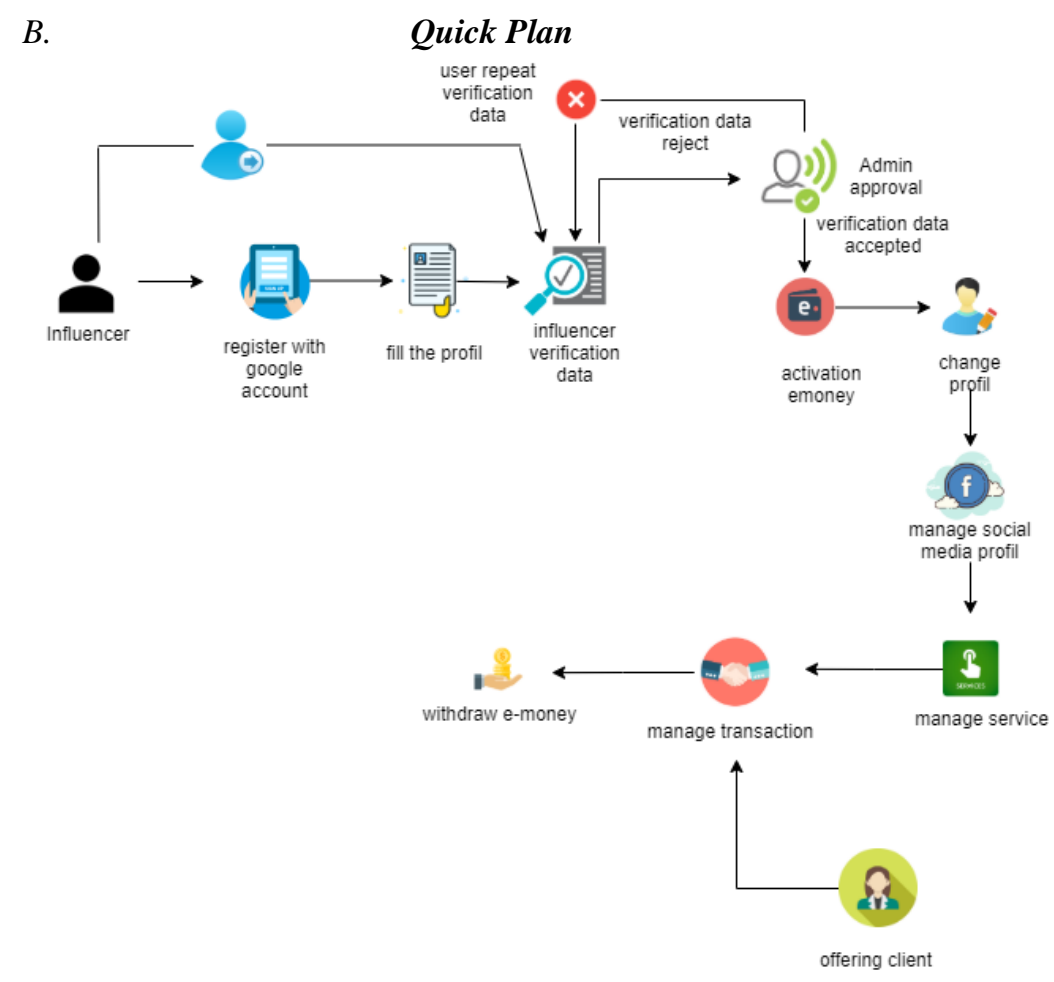

Figure 6 Influencer Activities

Influencer activity can be explained as follows;

1) The first step, influencers must register using a google account

2) The second step, influencers are required to fill out a profile

3) The third step, the user verifies the data

4) After verifying the data, the admin approves the user

5) After verification is received, the user is required to activate e-money
6) After e-money is active, the user can change the profile as needed

7) Then the user can also manage social media profiles

8) In addition to managing social media profiles, users can manage the services they provide

9) Furthermore, users can also manage incoming transactions originating from client offers

10) After the work is finished, the user can withdraw the e-money 


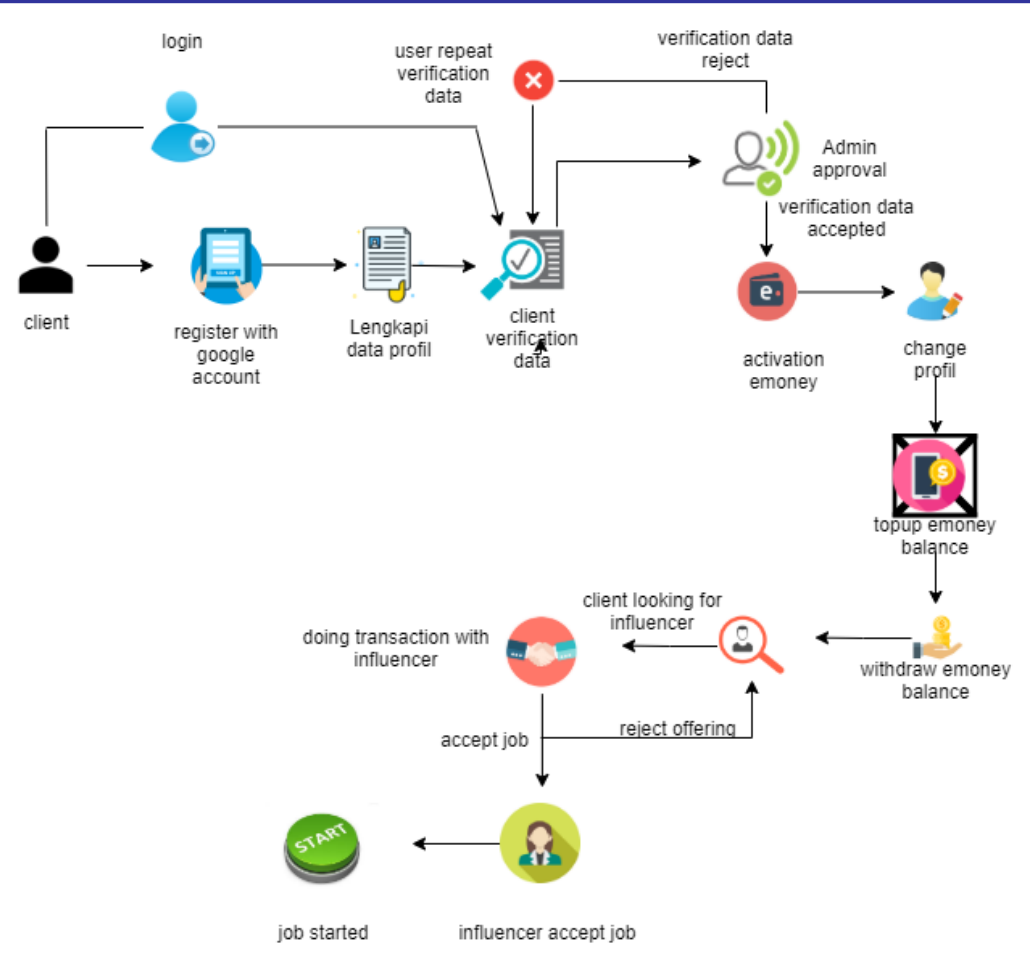

Figure 7 Client Activities

Client activity can be explained as follows;

1. The first step, client must register using a google account

2. The second step, client are required to fill out a profile

3. The third step, the user verifies the data

4. After verifying the data, the admin approves the user's verification

5. After verification is received, the user is required to activate e-money

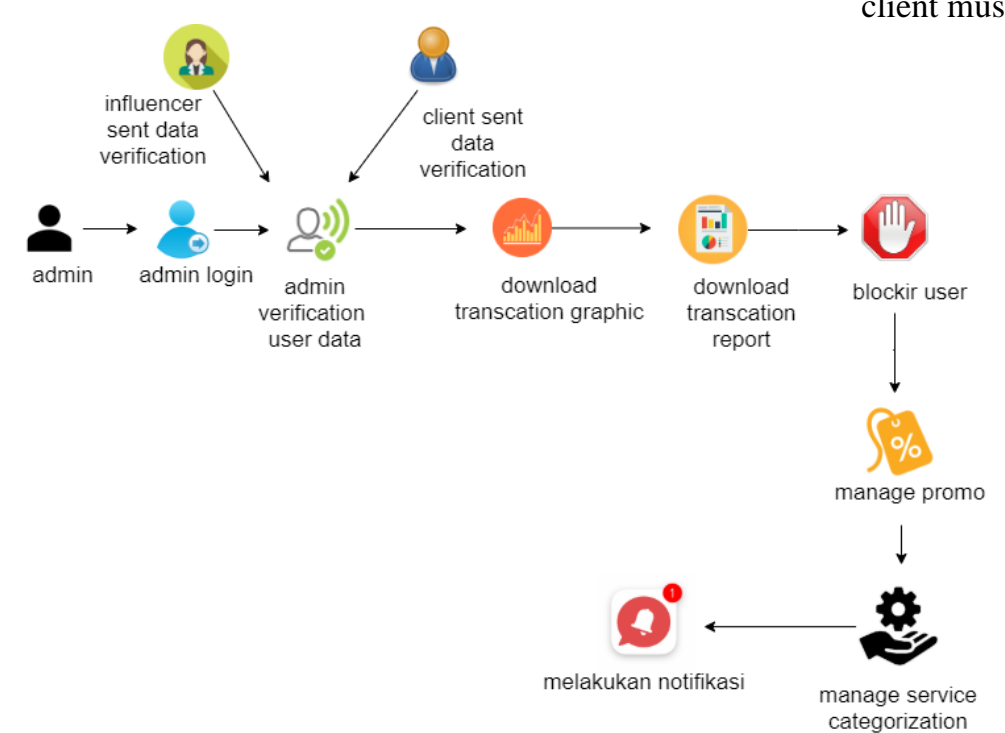

Figure 8 Admin activities
6. After e-money is active, the user can change the profile as needed

7. To start transaction, user must top up emoney balance

8. User also can withdraw e-money balance to their bank account

9. After set-up activation e-money, client can looking for influencer to their campaign

10. If client find the right influencer, client give offering to influencer. If influencer accept the offering, transaction starting from here. If influencer reject offering, so client must looking influencer again 
Admin activity can be explained as follows;

1. First, Admin users get login access that has been created by the developer.

2. The next step is conduct user approval. When the admin conducts a review of self-verification activities carried out by influencer / client users.

3. After approval process, admin can download transaction graphic as needed.

4. Admin also can do download transaction report as needed.
5. Other than that, admin can block user that identified as fraud.

6. Admin can manage on-going promo or to take down expired promo, manage service categorization.

7. For last step, admin can send notification for all user.The next step is conduct user approval. When the admin conducts a review of self-verification activities carried out by influencer / client users.

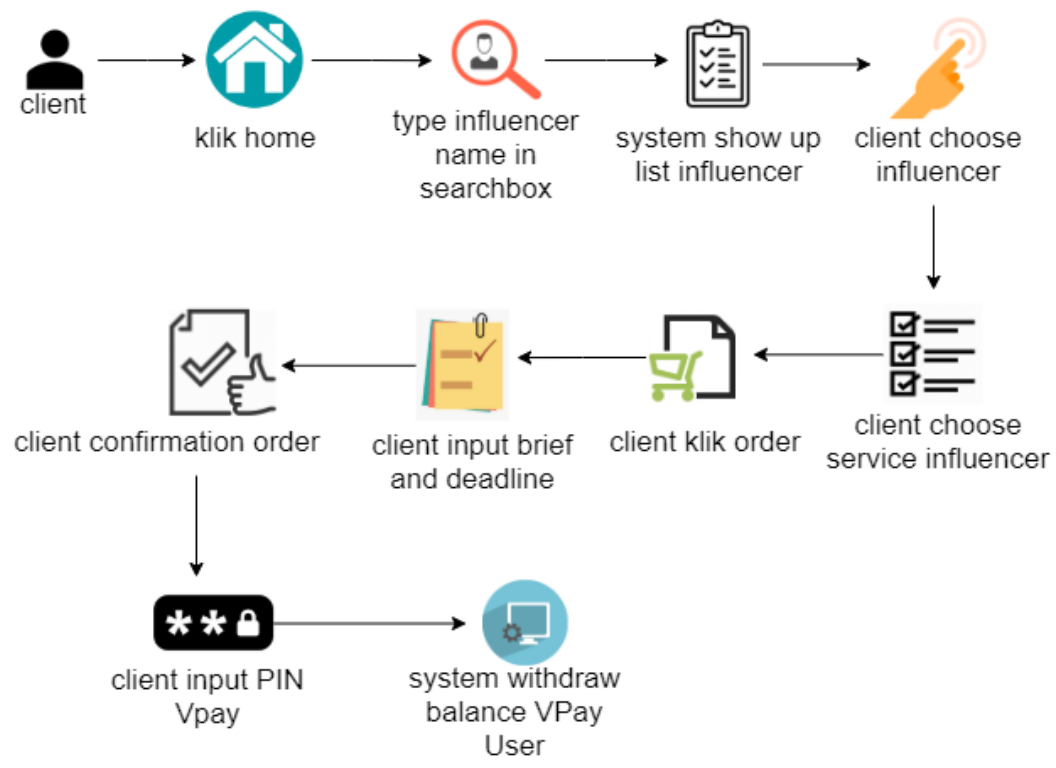

Figure 9 Client ordering influencer services

Activity client ordering influencers services can be explained as follows:

1. The first step, client click home.

2. Then, client type influencer's name in searchbox.

3. After that, system will show up list influencer.

4. Then, client choose influencer.

5. After seeing influencer's profil, client choose influencer's service
6. Then, client clik order.

7. Then, client input the brief and deadline.

8. After input brief and deadline, user click confirmation order.

9. The next step, client input Vpay PIN

10. Then, system will withdraw client balance.

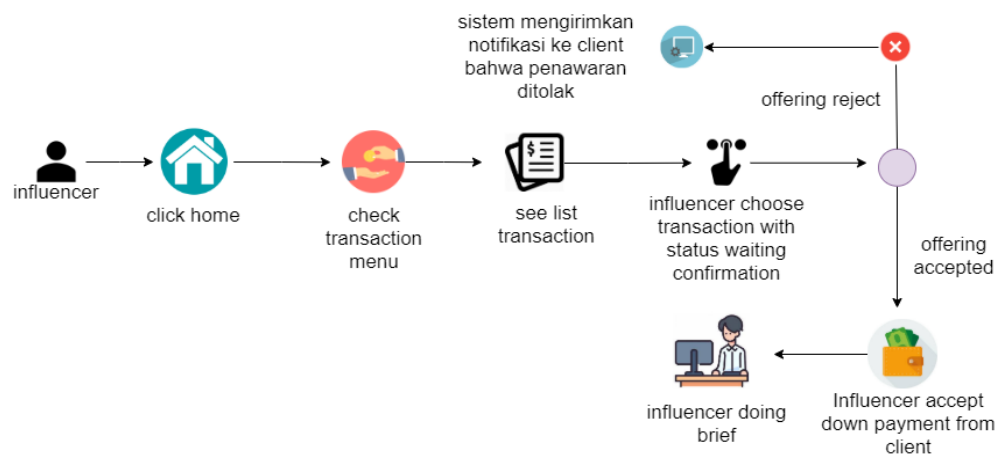

Figure 10 influencer confirmation order 
In the workflow confirmation line, it can be explained as follows:

1) For the first step the user enters the home page.

2) Then check the transaction menu.

3) The user sees a list of all transactions.

4) The next step, Influencers choose transactions with a waiting status for confirmation.

5) If the user accepts, the DP enters into the Vpay influencer account, if the system is rejected, the system sends an offer rejected to the email client.

6) After that, influencers work on briefs.

\section{Quick Design}

After analyzing the running business processes, problem analysis and needs analysis, it can be concluded that several flow systems contained in this application, among others; register, login and transaction.

\section{A. Application Interface for Influencer}

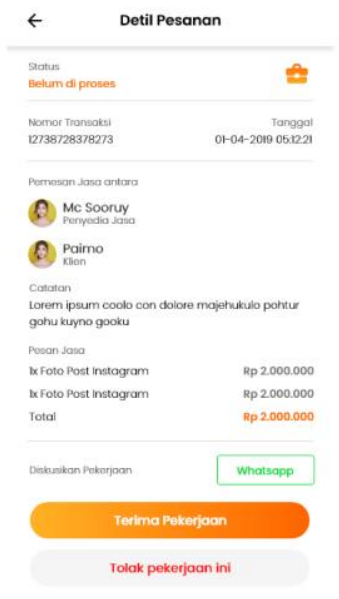

Application Interface for Influencer

Figure 11 Application Interface for Influencer

In this page, influencer users can do several activities, namely; view job summaries, arrange services, view notifications, find out V-Pay balances, and in this menu influencers can accept or reject jobs.

\section{B. Application Interface for Client}

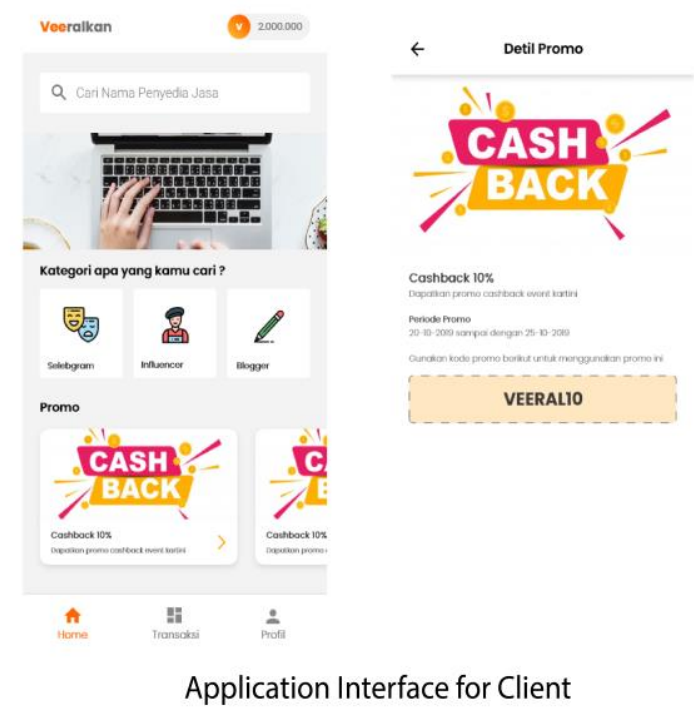

Figure 12 Application Interface for Client 
In this page, influencer users can do several activities, namely; know the V-pay balance, look for influencers by typing the name in the search box column, search for services according to the category see the promo that applies.

\section{CONCLUSION}

The following conclusions from this study are expected to make it easier for people to find influencers as needed.

1) In the Veeralkan application there is a Search Box to find influencers easily.

2) Veeralkan application is completed with transaction Terms and Conditions to prevent fraud

3) The Veeralkan application provides a DP transaction system that can be adjusted to the client's condition. In addition the Veeralkan application provides an automatic invoice system.

4) The Veeralkan application provides an e-money system, Vpay

5) The Veeralkan application is equipped with the Veeralkan Dashboard to monitor the entire transaction

\section{REFERENCE}

[1] Amita, P. (2015). EFEKTIVITAS MODEL PROBLEM BASED LEARNING ( PBL ) DISERTAI FISHBONE DIAGRAM ( FD ) UNTUK MEMBERDAYAKAN KEMAMPUAN MENGANALISIS. Premiere Educandum: Jurnal Pendidikan Dasar Dan Pembelajaran, 5(5), 223-238.

[2] APJII. (2017). Penetrasi \& Profil Perilaku Pengguna Internet Indonesia. Apjii, 51. Retrieved from www.apjii.or.id

[3] Bashar, A., Ahmad, I., \& Wasiq, M. (2012). Effectiveness of Social Media As a Marketing Tool: an Empirical Study. International Journal of Marketing, Financial Services \& Management Research, 1(11), 3622. Retrieved from www.indianresearchjournals.com

[4] Dehghani, M., Niaki, M. K., Ramezani, I., \& Sali, R. (2016). Evaluating the influence of YouTube advertising for attraction of young customers. Computers in Human Behavior, 59, 165172. https://doi.org/10.1016/j.chb.2016.01.037

[5] Hafiar, H. (2017). Peran Vlogger Sebagai Online Inflluencer dalam Industri Media Digital di Indonesia. Jurnal Promedia, 3(2), 183-206.

[6] Hanna, R., Rohm, A., \& Crittenden, V. L. (2011). We 're all connected: The power of the social media ecosystem. https://doi.org/10.1016/j.bushor.2011.01.007

[7] Hariyanti, N. T., \& Wirapraja, A. (2018). Pengaruh Influencer Marketing Sebagai Strategi Pemasaran Digital Era Moderen (Sebuah Studi Literatur). Jurnal Eksekutif, 15(1), 133-146.

[8] Hermanda, A., Sumarwan, U., \& Tinaprilla, N. (2019). THE EFFECT OF SOCIAL MEDIA INFLUENCER ON BRAND IMAGE , SELF-CONCEPT , AND PURCHASE INTENTION. Journal of Consumer Sciences, 04(02), 76-89.

[9] Keller, K. L. (2007). Marketing Management - 12. vydání. (October), 1-5. Retrieved from http://books.google.cz/books?id=pkWsyjLsfGgC

[10] Leung, X. Y., Bai, B., \& Stahura, K. A. (2015). The Marketing Effectiveness of Social Media in the Hotel Industry: A Comparison of Facebook and Twitter. Journal of Hospitality and Tourism Research, 39(2), 147-169. https://doi.org/10.1177/1096348012471381

[11] Öztamur, D., \& Karakadılar, İ. S. (2014). Exploring the Role of Social Media for SMEs: As a New Marketing Strategy Tool for the Firm Performance Perspective. Journal Procedia Social and Behavioral Sciences, 150, 511-520. https://doi.org/10.1016/j.sbspro.2014.09.067

[12] Patel, N. (2016). Digital Marketing Made Simple: A Step-by-
Step Guide. NeilPatel.Com/Blog, pp. 1-21. Retrieved from http://neilpatel.com/what-is-digital-marketing/

[13] Pradiptarini, C. (2011). Social Media Marketing: Measuring Its Effectiveness and Identifying the Target Market. Journal of Undergraduate Research , 14, 1-11.

[14] Pranoto, \& Salsabila, S. S. (2018). Eksistensi Kartu Kredit Dengan Adanya Electronic Money (E-Money) Sebagai Ala Pembayaran Pembayaran Yang Sah. Privat Law, 6(1), 24-33.

[15] Putra, A. K., Nyoto, R. D., \& Pratiwi, H. S. (2017). Rancang Bangun Aplikasi Marketplace Penyedia Jasa Les Private Di Kota Pontianak Berbasis Web. Jurnal Sistem Dan Teknologi Informasi, 5(1), 22-25.

[16] Rapp, A., Beitelspacher, L. S., Grewal, D., \& Hughes, D. E. (2013). Understanding social media effects across seller, retailer, and consumer interactions. Journal of the Academy of Marketing Science, 41(5), 547-566. https://doi.org/10.1007/s11747-013-0326-9

[17] Romero, D. M., Galuba, W., Asur, S., \& Huberman, B. A. (2011). Influence and passivity in social media. Journal Proceedings of the 20th International Conference Companion on World Wide Web, WWW 2011, 3(33), 113-114. https://doi.org/10.1145/1963192.1963250

[18] Royle, J., \& Laing, A. (2014). The digital marketing skills gap: Developing a Digital Marketer Model for the communication industries. International Journal of Information Management, 34(2), 65-73. https://doi.org/10.1016/j.ijinfomgt.2013.11.008

[19] SI, S. (2015). Social Media and Its Role in Marketing. Business and Economics Journal, 07(01), 1-5. https://doi.org/10.4172/2151-6219.1000203

[20] Siswanto, T. (2018). Optimalisasi Sosial Media Sebagai Media Pemasaran Usaha Kecil Menengah. Jurnal Liquidity, 2(1), 80 86. https://doi.org/10.32546/lq.v2i1.134

21] Stieglitz, S., \& Dang-Xuan, L. (2013). Social media an political communication: a social media analytics framework. Social Network Analysis and Mining, 3(4), 1277-1291. https://doi.org/10.1007/s13278-012-0079-3

[22] Sulistyo, P. B. (2018). Teenagers Preferences, Creations and Participation in Vlogging Activities. International Journal of Scientific and Research Publications (IJSRP), 8(8). https://doi.org/10.29322/ijsrp.8.8.2018.p80113

[23] Vance, K., \& Howe, W. (2009). Social Internet Sites as a Source of Public Health Information. Dermatologic Clinics, 27(2), 133-136. https://doi.org/10.1016/j.det.2008.11.010

[24] Whiting, A., \& Williams, D. (2013). Why people use social media: a uses and gratifications approach. Qualitative Market Research: An International Journal, 16(4), 362-369. https://doi.org/10.1108/QMR-06-2013-0041

[25] Yadav, M., Joshi, Y., \& Rahman, Z. (2015). Mobile Socia Media: The New Hybrid Element of Digital Marketing Communications. Journal of Procedia - Social and Behavioral Sciences, $\quad 189, \quad 335-343$. https://doi.org/10.1016/j.sbspro.2015.03.229 